\title{
Pengaruh Latihan Circuit Training Terhadap Peningkatan Vozmax Atlet Futsal Putra UNDIKMA
}

\author{
${ }^{1}$ Andi Anshari Bausad, ${ }^{2}$ Arif Yanuar Musrifin \\ ${ }^{1}$ Prodi Pendidikan Olahraga dan Kesehatan, Universitas Pendidikan Mandalika \\ Email Korespondensi: abausad@yahoo.com
}

\begin{abstract}
Abstrak. Tujuan dari penelitian ini adalah untuk mengetahui "ada atau tidak adanya Pengaruh Latihan Circuit Training terhadap peningkatan Vormax atlet futsal putra UNDIKMA". Metode penelitian yang digunakan adalah eksperimen dengan one grup pre test post test designe, instrument menggunakan bleep test. Populasi dalam penelitian ini adalah seluruh atlet putra futsal UNDIMKA yang berjumlah 10 orang dengan menggunakan studi populasi. Analisis data mengunakan uji $-\mathrm{t}$. Hasil Penelitian, didapatkan $t_{\text {hitung }} v_{2}$ max $_{\text {max }}$ sebesar 8,409 sedangkan jumlah $\mathrm{t}_{\text {tabel }}$ sebesar 1,833 dalam taraf signifikan $5 \%$ sehingga $t_{\text {hitung }}$ lebih besar dari pada $t_{\text {tabel }}(8,409>1.833)$. Kesimpulan penelitian ini menunjukan bahwa "Terdapat pengaruh latihan circuit training terhadap peningkatan Vozmax atlet futsal putra UNDIKMA.
\end{abstract}

\section{Kata kunci: Circuit Training, $\operatorname{Vo}_{2} \max$, Futsal}

Abstract. The purpose of this study was to determine whether or not there is an effect of circuit training training on the increase in Vormax of male futsal athletes at UNDIKMA. The research method used was an experiment with one group pre test post test design, the instrument used the bleep test. The population in this study were all 10 male athletes of futsal UNDIMKA using population studies. Data analysis using t-test. The results showed that the Vormax $t$-count was 8.409 , while the $t$-table was 1.833 at the 5\% significant level so that the $t$-count was greater than the t-table (8.409>1.833). The conclusion of this study shows that there is an effect of circuit training on increasing the Vormax of male futsal athletes at UNDIKMA.

Kata kunci: Circuit Training, Vormax, Futsal

\section{PENDAHULUAN}

Pengertian latihan yang berasal dari kata practice adalah aktivas untuk meningkatkan keterampilan (kemahiran) berolahraga dengan menggunakan berbagai peralatan sesuai dengan tujuan dan kebutuhan cabang olahraganya. Artinya, selama dalam kegiatan proses berlatih melatih agar dapat menguasai keterampilan gerak cabang olahraganya selalu dibantu dengan menggunakan berbagai peralatan mendukung. Biasanya setiap dalam waktu interval 3 sampai 4 minggu latihan telah berjalan, selalu dilakukan pemantauan pencapaian hasil latihan. Dengan demikian setiap sesi latihan harus mempunyai sasaran dan tujuan yang nyata dan terukur (Sukadiyanto, 2011).

Menurut hasil pengamatan yang dilakukan peneliti sekaligus sebagai pelatih futsal atlet futsal UNDIKMA, selama tim futsal mengikuti pertandingan, atlet terlihat mengalami kelelahan ketikan melakukan pertandingan. Diakibatkan kurangnya daya tahan jantung paru seorang pemain. Maka dari itu peneliti ingin memberikan model latihan circuit training. Sukadiyanto 2011, circuit training mempunyai pengaruh pada daya tahan kardiovaskuler, dan bisa menguatkan otot-otot pernafasan, hal tersebut memberi manfaat besar pada pemeliharaan kebugaran jantung dan paru-paru. Bausad \& Musrifin,2018. Daya tahan kardiorespiratory dalam permainan futsal berfungsi untuk menjaga stamina atau atlet mampu bermain penuh waktu tanpa mengalami kelelahan. Sedangkan daya tahan otot berfungsi untuk penunjang tehnik dasar, seperti shotting, dribbling, dan body contact dengan pemain lawan.

Ferry Robiansyah \& Fahrial Amiq, 2018, latihan sirkuit merupakan suatu jenis program latihan yang berinterval di mana latihan 
kekuatan digabungkan dengan latihan aerobik, yang juga menggabungkan manfaat dari kelenturan dan kekuatan fisik. "Sirkuit" disini berarti beberapa kelompok olahraga atau pos yang berada di area dan harus diselesaikan dengan cepat di mana tiap peserta atau atlet harus menyelesaikan satu pos dahulu sebelum ke pos berikutnya. Adapun model latihan yang akan terapkan yaitu: 1. Skiping dilakukan selama 30 detik, 2. Pus up dilakukan selama 30 detik, 3. Zig-zag dilakukan selama 30 detik dengan jarak 5 meter, 4. Lompat Zebra dilakukan selama 30 detik dengan jarak 10 meter, 5. Sprint dilakukan selama 30 detik dengan jarak 20 meter dan jarak antara pos 1 dengan pos yang lainnya 5 meter.

Aktivitas olahraga futsal merupakan permainan bola yang dimainkan oleh dua tim, yang masing-masing beranggotakan lima orang. Selain lima pemain utama, setiap regu juga diizinkan mempunyai pemain cadangan. Tipe kondisi fisik permainan ini tidaklah sama dengan permainan sepak bola dikarenakan permainan futsal mempunyai karakteristik permainan yang cepat antara posisi bertahan dan menyerang, dalam waktu bermain $2 \times 15$ menit permainan tidak akan berhenti berlari, bergerak dan bertukar posisi.

Dalam permainan futsal sangat dibutuhkan keahlian dan pembinaan yang lebih dari beberapa cabang olahraga lainnya, sehingga dalam permainan bisa bermain dengan baik dan terlihat menarik. Seorang pemain selain harus memiliki mobilitas tinggi, mengerti taktik dan strategi serta mampu membaca kekuatan lawan dan dimana letak kelemahannya. Pemain juga harus tahu seberapa besar kebugaran jasmani yang dimiliki. Salah satu komponen terpenting dari empat komponen kebugaran jasmani yang berhubungan dengan kesehatan adalah daya tahan kardiorespirasi. Faktor kebugaran jasmani tidak kalah pentingnya dalam permainan futsal, tujuannya adalah agar pemain mampu bertahan dalam bermain futsal tanpa mengalami kelelahan. Hal tersebut berkaitan dengan permainan futsal membutuhkan daya tahan kardiorespirasi. Menurut Ismaryati (2006:77) menyatakan, Istilah konsumsi oksigen maksimal mempunyai pengertian yang sama dengan maximal oxygenintake dan maximal oxygen power yang menunjukkan perbedaan yang terbesar antara oksigen yang dihisap masuk ke dalam paru dan oksigen yang dihembuskan ke luar paru. Seorang pemain futsal yang memiliki daya tahan paru jantung baik, tidak akan cepat kelelahan dalam bermain futsal.

Kualitas daya tahan paru jantung dinyatakan dengan vozmax, yaitu banyaknya oksigen maksimum yang dapat dikonsumsi dalam satuan $\mathrm{ml} / \mathrm{kg} / \mathrm{bb} / \mathrm{menit}$. Dalam permainan futsal, kemampuan daya tahan aerobik yang baik atau vormax yang tinggi sangat diprioritaskan. Apabila kedua pemain dengan kemampuan yang hampir sama, maka kalah atau menang ditentukan oleh kondisi fisiknya dan mental seorang pemain. Maka dari itu dapat dikatakan bahwa daya tahan aerobik atau vo vax $_{2}$ menjadi salah satu faktor penentu kemenangan dalam permainan futsal.

Kualitas daya tahan paru jantung dinyatakan dengan $v_{2} \max$, yaitu banyaknya oksigen maksimum yang dapat dikonsumsi dalam satuan $\mathrm{ml} / \mathrm{kg} / \mathrm{bb} / \mathrm{menit}$. Dalam permainan futsal, kemampuan daya tahan aerobik yang baik atau vormax yang tinggi sangat di prioritaskan. Apabila kedua pemain dengan kemampuan yang hampir sama, maka kalah atau menang ditentukan oleh kondisi fisiknya dan mental seorang pemain. Maka dari itu dapat dikatakan bahwa daya tahan aerobik atau vo 2 max menjadi salah satu faktor penentu dalam permainan futsal.

Berdasarkan permasalahan di atas peneliti ingin melakukan penelitian tentang "Pengaruh Latihan Circuit Training terhadap peningkatan Vo:max atlet futsal putra UNDIKMA.

\section{METODE PENELITIAN}

Rancangan penelitian merupakan penjelasan bagaimana penelitian itu dilakukan dan menggunakan jenis penelitian apa pada pelaksanaan penelitian (Lalu Hulfian, 2014:81). Sehubungan dengan penelitian ini, maka rancangan penelitian menggunakan : "One group pre-test, post-test Design atau yang disebut juga dengan treatment by subjects design" (Lalu Hulfian, 2014:38). Adapun 
bentuk perancangan yang dimaksud adalah seperti yang tertera pada gambar di bawah ini :

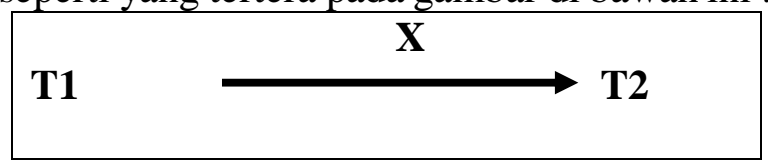

2014)

Gambar 1. Rancangan penelitian (Hulfian,

Keterangan

T1 : Pre-test (tes awal),

X : Treatmen (perlakuan), cirkuit training

T2 : Pre-test (tes akhir)

Subyek penelitian ini adalah Atlet futsal putra UNDIKMA yang berjumlah 10 mahasiswa, dikarenakan kondisi pandemi covid 19, atlet futsal putra UNDIMA yang bersedia ikut dan rajin datang selama pemberian treatment atau perlakuan penelitian berlangsung 4 bulan (penelitian dilaksanakan mulai bulan Juni-Oktober), dalam satu minggu 3 kali latihan. Bompa (2015) yakni: Frekuensi pelatihan sebaiknya 3 kali perminggu, sirkuit dilakukan 2-3 tiap pos, 6-15 pos, beban latihan antara 40\%-50\% dari maksimal ulangan tunggal, jumlah repetisi tiap pos $75 \%$ - $100 \%$ dari jumlah maksimal yang bisa di capai dari periode kerja, dan periode kerja 15-30 detik dan periode waktu istirahat 15-60 detik. Jadi teknik pengamabilan sampelnya dalam penelitian menggunakan studi populasi. Studi populasi adalah teknik penentuan sampel bila semua anggota populasi bisa dijadikan sampel. Hal ini sering dilakukan bila jumlah sampel populasi relatif kecil kurang dari 100 orang, atau penelitian yang ingin membuat generalisasi dengan kesalahan yang sangat kecil, (Lalu Hulfian, 2014). Selama pemberian treatment atau perlakukan dilaksanakan di lapangan futsal UNDIKMA, dengan mengunakan protokol kesehatan ketat, seperti pengecekan suhu badan, pengunaan masker standar, dan pengunaan sarung tangan, dan mencuci tangan.

Instrumen dalam penelitian ini adalah instrumen tes $\mathrm{VO}_{2} \max$ Blepp test.

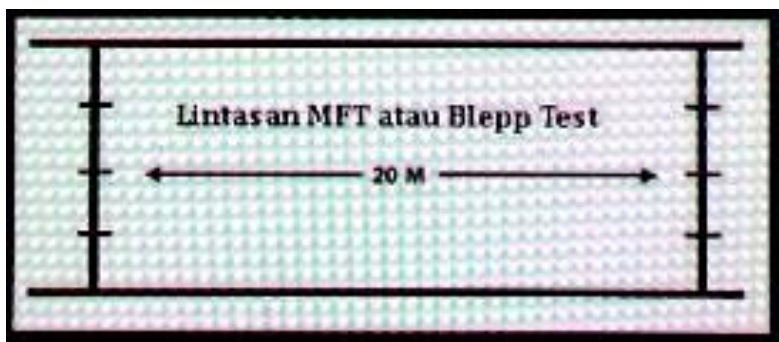

Gambar 2. Lapangan/Lintasan Multi Stage Fitness Test

Prosedur pelaksanaan tes bleep adalah sebagai berikut.

a. Tes bleep dilakukan dengan lari menempuh jarak 20 meter bolak-balik, yang dimulai dengan lari pelan-pelan secara bertahap yang semakin lama semakin cepat hingga atlet tidak mampu mengikuti irama waktu lari, berarti kemampuan maksimalnya pada level bolak-balik tersebut.

b. Waktu setiap level 1 menit.

c. Pada level 1 jarak 20 meter ditempuh dalam waktu 8,6 detik dalam 7 kali bolakbalik.

d. Pada level 2 dan 3 jarak 20 meter ditempuh dalam waktu 7,5 detik dalam 8 kali bolakbalik.

e. Pada level 4 dan 5 jarak 20 meter ditempuh dalam waktu 6,7 detik dalam 9 kali bolakbalik, dan seterusnya.

f. Setiap jarak 20 meter telah ditempuh, dan pada setiap akhir level, akan terdengar tanda bunyi 1 kali.

g. Start dilakukan dengan berdiri, dan kedua kaki di belakang garis start. Dengan abaaba "siap ya", atlet lari sesuai dengan irama menuju garis batas hingga satu kaki melewati garis batas.

h. Bila tanda bunyi belum terdengar, atlet telah melampuai garis batas, tetapi untuk lari balik harus menunggu tanda bunyi. Sebaliknya, bila telah ada tanda bunyi atlet belum sampai pada garis batas, atlet harus mempercepat lari sampai melewati garis batas dan segera kembali lari ke arah sebaliknya.

i. Bila dua kali berurutan atlet tidak mampu mengikuti irama waktu lari berarti kemampuan maksimalnya hanya pada level dan balikan tersebut. 
j. Setelah atlet tidak mampu mengikuti irama waktu lari, atlet tidak boleh terus berhenti, tetapi tetap meneruskan lari pelan-pelan selama 3-5 menit untuk cooling down. (Kemenegpora, 2005)

Lebih lanjut, tehnik analisis data yang digunakan dalam penelitian ini adalah tehnik analisis data statistik dengan mengunakan Uji $\mathrm{t}$, adapun rumus untuk menyelesaikan sebagai antara lain:

$\mathbf{t}=\frac{\sum \mathbf{D}}{\sqrt{\frac{N \cdot \sum \mathbf{D}^{2}-\left(\sum \mathbf{D}\right)^{2}}{(N-1)}}}$

(Lalu Hulfian, 2014)

Keterangan :

$\mathrm{D}=$ Perbedaan setiap pasangan skor (post-test - pre-test)

$\mathrm{N}=$ jumlah sampel yang digunakan

\section{HASIL DAN PEMBAHASAN}

\section{A. Hasil Penelitian}

1. Tabel hasil pre test kemampuan $v o_{2} \max$ atlet futsal putra UNDIKMA.

\begin{tabular}{|c|l|c|c|c|}
\hline No & Nama & Level & Balikan & Vo2max \\
\hline 1 & A & 6 & 2 & 33.6 \\
\hline 2 & B & 6 & 3 & 33.9 \\
\hline 3 & C & 5 & 9 & 32.9 \\
\hline 4 & D & 6 & 5 & 34.6 \\
\hline 5 & E & 6 & 4 & 34.3 \\
\hline 6 & F & 5 & 6 & 31.8 \\
\hline 7 & G & 6 & 3 & 33.9 \\
\hline 8 & H & 6 & 7 & 35.3 \\
\hline 9 & I & 6 & 8 & 35.7 \\
\hline 10 & J & 7 & 1 & 36.7 \\
\hline \multicolumn{5}{|c|}{ Jumlah } \\
\hline
\end{tabular}

2. Tabel hasil post test kemampuan vo 2 max atlet futsal putra UNDIKMA.

\begin{tabular}{|c|l|c|c|c|}
\hline No & Nama & Level & Balikan & Vo2max \\
\hline 1 & A & 7 & 6 & 38.5 \\
\hline 2 & B & 7 & 4 & 37.8 \\
\hline 3 & C & 6 & 3 & 33.9 \\
\hline 4 & D & 7 & 2 & 37.1 \\
\hline 5 & E & 6 & 9 & 36.0 \\
\hline 6 & F & 6 & 6 & 35.0 \\
\hline 7 & G & 7 & 6 & 38.5 \\
\hline 8 & H & 7 & 8 & 39.2 \\
\hline 9 & I & 7 & 8 & 39.2 \\
\hline
\end{tabular}

Jurnal Ilmu Sosial dan Pendidikan

\begin{tabular}{|r|r|r|r|r|}
10 & $\mathbf{J}$ & 8 & 3 & 40.8 \\
\hline \multicolumn{3}{|c|}{ Jumlah } & $\mathbf{3 7 6}$ \\
\hline
\end{tabular}

\section{Tabel kerja}

Data Pre-test dan Post-test yang diperoleh di atas kemudian dianalisis untuk mendapat nilai sehingga dapat memberikan indikator hasil penelitian ini.

\begin{tabular}{|c|l|c|c|c|c|}
\hline No & Nama & $\begin{array}{c}\text { Pre } \\
\text { test }\end{array}$ & $\begin{array}{c}\text { Post } \\
\text { test }\end{array}$ & D & $\mathbf{D}^{\mathbf{2}}$ \\
\hline 1 & $\mathrm{A}$ & 33.6 & 38.5 & 4.9 & 24.01 \\
\hline 2 & $\mathrm{~B}$ & 33.9 & 37.8 & 3.9 & 15.21 \\
\hline 3 & $\mathrm{C}$ & 32.9 & 33.9 & 1 & 1 \\
\hline 4 & $\mathrm{D}$ & 34.6 & 37.1 & 2.5 & 6.25 \\
\hline 5 & $\mathrm{E}$ & 34.3 & 36.0 & 1.7 & 2.89 \\
\hline 6 & $\mathrm{~F}$ & 31.8 & 35.0 & 3.2 & 10.24 \\
\hline 7 & $\mathrm{G}$ & 33.9 & 38.5 & 4.6 & 21.16 \\
\hline 8 & $\mathrm{H}$ & 35.3 & 39.2 & 3.9 & 15.21 \\
\hline 9 & $\mathrm{I}$ & 35.7 & 39.2 & 3.5 & 12.25 \\
\hline 10 & J & 36.7 & 40.8 & 4.1 & 16.81 \\
\hline \multicolumn{2}{|c|}{ Jumlah } & & & $\mathbf{3 3 . 3}$ & $\mathbf{1 2 5 . 0 3}$ \\
\hline
\end{tabular}

Dengan demikian, untuk memasukan data ke dalam rumus, langkah terakhir dalam menghitung data-data dengan statistik (rumusrumus) adalah dengan menghitung nilai perbandingan antara tes awal (pre-test) dan tes akhir (post-test) dengan menggunakan rumus " $t$ " test sebagai berikut:

$$
\begin{gathered}
t=\frac{\sum D}{\sqrt{\frac{N \cdot \sum D^{2}-\left(\sum D\right)^{2}}{(N-1)}}} \\
t=\frac{33,3}{\sqrt{\frac{10.125,03-(33,3)^{2}}{(10-1)}}} \\
t=\frac{33.3}{\sqrt{\frac{1250,3-1108,89}{9}}} \\
t=\frac{33,3}{\sqrt{\frac{141.41}{9}}} \\
t=\frac{33,3}{\sqrt{15,71}} \\
t=\frac{33,3}{3,96} \\
t=8,409
\end{gathered}
$$

Setelah kita mendapatkan nilai t-hitung, diperoleh maka nilai t-hitung menunjukan nilai sebesar 8,409 kemudian nilai t-tabel dengan derajat bebas (db) $\mathrm{N}-1=10-1=9$ pada taraf signifikan 5\%, maka t-tabel 1,833. Dari hasil ini berarti bahwa t-hitung > t-tabel, yaitu $(8,409>1.833)$.

Berdasarkan nilai t-hitung lebih besar dari angka penolakan hipotesis nihil (Ho) yang 
tercantum dalam tabel nilai " $t$ " berdasarkan kenyataan diatas yaitu t-hitung lebih besar dari t-tabel, dengan demikian nilai t-hitung yang diperoleh dalam penelitian ini adalah signifikan

\section{PEMBAHASAN}

Karakteristik olahraga futsal adalah olahraga yang identik mempunyai pergerakan cepat antara menyerang dan bertahan, dengan luas lapangan yang tidak sebesar lapangan sepak bola maka dibutuhkan daya tahan kecepatan, daya tahan kekuatan, daya tahan kelincahan dan kemampuan data tahan jantung dan paru atau Vo 2 max yang sangat baik. Menurut Lhaksana (5:2012), Futsal dalam bahasa Spanyol nya adalah "futbol sala"yang berarti sepak bola dalam ruangan. Menurut Amiq (2014:4), futsal adalah sepakbola mini di dalam ruangan yang menuntut para pemain untuk melakukan pergerakan yang dinamis dan cepat, dengan tujuan menekan daerah lawan dan membuat gol sebanyak mungkin. Pemain futsal dituntut memiliki kondisi fisik yang prima, karena kondisi fisik yang prima sangatlah menunjang penampilan seorang pemain. Jika kondisi fisik yang dimiliki pemain futsal itu buruk, tentunya berdampak buruk juga terhadap teknik dan taktiknya. Zusyah \& Khoirul Hidayat, 2015, Pengaruh gerak merupakan konsep yang dikaitkan dengan pengaruh pengalaman gerak pada pelaku. Pengaruh kelincahan dan tipe latihan yang menghasilkan daya tahan, kekuatan, dan kelentukan merupakan konsep pengaruh gerak. Proses yang dilibatkan dalam prinsip pengajaran gerak adalah sesuatu yang dimulai dari mendefinisikan konsep dan membantu siswa mengerti prinsip-prinsip tersebut diikuti dengan membantu siswa menggeneralisasikan prinsip tersebut pada seluruh situasi yang memungkinkan.

Latihan circuit training tanpa bola yakni dapat digunakan untuk meningkatkan VO2 Max dan daya tahan otot. Program circuit traning telah dimanfaatkan oleh banyak profesional tim sepakbola di Inggris dan tim kompetitif di Australia (Kumar, 2013). Menurut Venkatachalapathy (2015) Latihan circuit merupakan model latihan yang mengkombinasikan antara latihan kekuatan, power, kecepatan, dan latihan daya tahan anaerobic atau pun daya tahan aerobic. Latihan circuit dapat dikatakan dapat mempengaruhi kualitas stamina atlet dalam jangka pendek. Hal ini dikarenakan latihan circuit mencakup hampir semua komponen kondisi fisik yang dilakukan dengan tempo tinggi secara serempak dalam waktu yang relatif singkat. Menurut Bompa (2015:231), karakteristik yang harus diperhatikan dalam mengembangkan program latihan sirkuit yaitu. Pelatihan sirkuit pendek terdiri 6-9 butir latihan, menengah 10-12 butir latihan, atau sirkuit panjang 13-15 butir latihan dan dapat diulang dengan jumlah waktu tertentu, tergantung pada jumlah latihan yang dimasukkan yaitu latihan yang lebih banyak, dengan pengulangan latihan sirkuit yang sedikit.

Hasil pembahasan diatas sesuai dengan hasil penelitian relevan yang ada terkait latihan circuit training terhadap peningkatan kapasitas jantung dan paru atau Vormax. Mia Kusumawati, 2014. Sirkuit Training memberikan peningkatan daya tahan tubuh atlit futsal yang signifikan. Instrument tes Vormax mengunakan lari $2.4 \mathrm{Km}$.

Kondisi fisik merupakan salah satu penunjang prestasi atlet yang sangat penting selain dari teknik, taktik dan mental. Perencanaan program latihan kondisi fisik harus direncanakan dengan baik, hal ini secara sistematis untuk meningkatkan daya tahan dan kemampuan fungsional dari sistem tubuh sehingga dapat menimbulkan pemain mencapai prestasi yang lebih baik sesuai harapan. Salah satu bentuk kondisi fisik yang sangat dominan oleh seorang pemain adalah daya tahan tubuh, baik daya tahan jantung ataupun otot. Daya tahan dapat diartikan sebagai waktu bertahan yaitu lamanya seseorang melakukan suatu intensitas kerja atau jauh dari keletihan.

\section{KESIMPULAN}

Terdapat pengaruh latihan circuit training terhadap peningkatan $\mathrm{Vo}_{2}$ max atlet futsal putra UNDIKMA.

\section{SARAN}


Peneliti selanjutnya, untuk meneliti lebih lanjut terkait pengunaan latihan circuit training mengunakan bola, dikarenakan penelitian ini dilaksanakan latihan circuit training tidak menggunakan bola. Sehingga untuk kedepan lebih bervaritaif latihan yang digunakan dan dapat mengetahui dampak atau hasil mana yang lebih baik latihan circuit training yang mengunakan bola dan tidak mengunakan bola pada olahraga futsal.

\section{DAFTAR PUSTAKA}

Amiq, Fahrial. 2014. FUTSAL (Sejarah, Teknik Dasar, Persiapan Fisik, Strategi, dan Peraturan Permainan). Malang: UniversitasNegeri Malang.

Bausad, Andi Anshari. dan Musrifin, Arif Yanuar. 2018. Metode Sport masase Sebagai Pemulihanan Pasif Dalam Peningkatan Kapasitas Daya Tahan Maksimal (Vo2max) Atlet Futsal Ikip Mataram. JISIP. Vol. 2 No. 3 ISSN 2598-9944, Nopember 2018.

Bompa, (2015). Periodization Training for Sports. Unitted States : Human Kinetics.

Hulfian, L. 2014. Statistik Dikjas. Selong: CV. Garuda Imu.

Ismaryati. 2006. Tes Dan Pengukuran Olahraga. Surakarta: Sebelas Maret University Press.

Kementerian Negara Pemuda Dan Olahraga Republik Indonesia, 2005. Panduan Penetapan parameter tes Pada pusat pendidikan dan pelatihan pelajar dan sekolah khusus olahragawan. Jakarta.

Kumar, V. (2016). Effect of Circuit Training Program on Selected Motor Abilities Among University Male. International Jurnal of Physical Education, Sport And Health. 3 (4), 255-257.

Lhaksana, Justinus. (2012). Teknik dan Strategi Futsal Modern. Jakarta: Be Champion

Mia Kusumawati, 2014. Pengaruh Circuit training terhadap Daya Tahan Atlet Futsal Swap Jakarta Dalam indonesia Futsal League (Ifl) 2013. Jurnal
Pendidikan Olah Raga, Vol. 3, No. 1, Juni 2014.

Robiansyah Ferry, Amiq Fahrial. 2018. Pengembangan Model Latihan (Circuit Training) Dalam Permainan Futsal. Prosiding Seminar Nasional IPTEK Olahraga, 2018, ISSN 26220156.

Sukadiyanto. 2011. Pengantar Teori dan Metodologi Melatih Fisik. Bandung:

CV Lubuk Agung.

Venkatachalapathy R. (2015). Effect Circuit Training Programme on Speed and Agility. International Journal of Recent Research and Aplied Studies. 2 (2), 71-72.

Zusyah Porja Daryanto, Khoirul Hidayat, 2015. Pengaruh Latihan Kelincahan Terhadap Kemampuan menggiring Bola. Jurnal Pendidikan Olahraga, Vol. 4, No. 2, Desember 201. 